\title{
Cyanotoxins removal from the water: a review
}

\author{
Evaldo de Melo Ferreira ${ }^{1} \&$ Keila Castro Oliveira ${ }^{3}$
}

${ }^{1}$ Master of Science, PhD student, Environmental and Sanitary Department, Federal University of Minas Gerais, Belo Horizonte, Minas Gerais, Brazil

${ }^{2}$ Master of Science, PhD student, Civil Engineering Department, Federal University of Viçosa, Viçosa, Minas Gerais, Brazil

\begin{abstract}
The aim of this work is to show the state-of-the-art about powdered activated carbon and cyanotoxins removal, normally used to avoid health problems in drinking water. The work is part of the PhD research of the second author. Brazilian government has one important law about the subject, named as ordinance 2.914, which provides procedures for water quality control and monitoring. In addition, the standards of portability. Problems caused by cyanotoxins are discussed as one the most dangerous for the public health. The problems linked with cyanobacteria for a long time have been neglected. Some of the problems caused for the presence of this toxins in the water are gastroenteritis, hepato-enteritis and other diseases of the liver and kidney, cancer, skin irritations, allergies, conjunctivitis, vision problems, muscle weakness, respiratory problems, asphyxia, seizures and in extreme cases death. Papers from different bases were consulted as materials in this research. The main bases were Scopus, Science Direct, and SciELO.
\end{abstract}

Keywords: Sanitation, Environmental control, Environmental Engineering, Water quality. 


\section{Introduction}

Water is essential for the maintenance of life in its different forms and presents multiple uses, among them the human consumption and the use in the natural cycles, to guarantee the ecological balance. The scarcity of clean, safe drinking water is still one of the main mortality factors in developing countries (BOUTILIER et al., 2014).

Brazil is a continental country located between tropical and subtropical zones, and its inland waters represented by streams, rivers, dams, lakes and shallow coastal lagoons (ANDRADE \& GIROLDO, 2014). Urban expansion and alteration of natural environments cause negative results on these waters.

An example for point sources of pollution are releases of untreated wastewater. As examples of constituents responsible for water pollution, there are organic matter, nitrogenous and phosphate compounds, pesticides, heavy metals, among others (JING et al., 2013).

The shortage of water resources has worsened and requires the use of measures to improve the management of supply and demand of water for different uses. Thus, maintenance of water supply, not only in sufficient quantity, but also with adequate quality, is one of the major challenges of the 21st century (LOPES et al., 2014). Before the capture of the water used for the human supply, it is essential to know the quality of the spring, measured by means of physical, chemical and biological variables (BARRETO et al., 2014) that are monitored by means of laboratory tests and examinations. BERTOSSI et al., 2013). To determine the quality of the raw water, it is necessary to consider the quality of the raw water, which generates savings in the treatment phase (BERTOSSI et al., 2013).

For water, be used for public supply, different treatment steps are required, designed per the characteristics of raw water and potability standards. In the potabilization of water from surface sources, physical, chemical and biological processes can be used to remove impurities, be they from anthropic activities in the contribution basin or even from natural sources, such as leaching of the soil, which ultimately mobilizes Ions and other organic substances.

This set of unit operations can promote the removal of sedimentable solids and organic matter, the inactivation of pathogenic organisms and the adsorption of pesticides, depending on the target pollutant (BRIDGEMAN et al., 2014). The level of contamination and water pollution determines the existence of these different stages, and the safety and reliability of drinking water have become one of the most important goals for quality management (TIAN et al., 2014). Based on the concept of multiple barriers.

The occurrence of emerging pollutants, such as pharmaceuticals, endocrine disrupters and pesticides in water, has become a significant concern in recent years (NAN et al., 2014). The study of technologies that make up the so-called "advanced water treatment" aims at the removal of specific pollutants, whose occurrence in the water sources has become more common due to an increasingly 
sophisticated society, consumer of natural resources and waste generator.

The aggravation of pollution and the changes related to water quality impose a new challenge that is the updating and improvement of conventional treatment processes (DONG et al., 2014), with focus on the emerging pollutants, within which cyanotoxins are found. These are synthesized by cyanobacteria, a phytoplanktonic group that can proliferate excessively in aquatic environments, in which they form thick blue-green layers on the water surface because of artificial eutrophication. These microorganisms are prokaryotes that perform photosynthesis and have a wide diversity of forms due to the morphological, biochemical and physiological adaptations acquired during their long evolutionary process (KURIIAMA et al., 2012). Examples of cyanobacteria are Anabaena flos-aquae, Microcystis aeruginosa and Cylindrospermopsis raciborskii. These species are potentially cyanotoxin producers (RESTANI \& FONSECA, 2014). The aim of this work is to show the state-of-the-art about powdered activated carbon and cyanotoxins removal, normally used to avoid health problems in drinking water.

\section{Cyanotoxins and ways to remove}

Phytoplankton proliferation may be a natural phenomenon, associated with an ideal nutrient balance and temperature rise, for example, which may be favorable conditions for algae and cyanobacteria blooms (JARDIM et al., 2014). This is a very important factor for the cyanobacteria, which is the system of winds and pluviometry in the area, which affect the water column mixing conditions and their physical, chemical and biological characteristics (OGASHAWARA et al., 2014). More than 1,000 species of cyanobacteria are known. To date, however, only forty have been described as capable of producing cyanotoxins, which are substances that produce toxic effects and can act on neurotransmitters of the central and peripheral nervous system, liver cells, gastrointestinal system and mucosal tissues, as well as causing irritation and allergic effects (SORLINI et al., 2013, AL-SAMMAK et al., 2014). Cyanotoxins with hepatotoxic, neurotoxic and dermatotoxic effects can be found in contaminated food and water and have potential for bioaccumulation in the food chain. Microcystins may represent the group most associated with cases of intoxication, becoming a focus of attention in several countries (MINILLO et al., 2013), although the saxitoxins and the cylinderspermopsins are also the subject of studies.

Microcystins are cyclic heptapeptides, which have a structure characterized by D-alanine 1-X 2 -DMeAsp 3 -Z 4 -Add 5 -D-glutamate 6-Mdha 7. X and Z represent two variable L-amino acids, DMeAsp corresponds to D-erythro- $\beta$-methyl aspartic acid and Mdha is equivalent to N-methyl- 
hydroalanine. The control of cyanotoxins in water is due to the association of preventive and corrective aspects. To prevent the flowering of cyanobacteria and, consequently, to minimize the production of such toxins, it is essential to reduce the contribution of nutrients (phosphorus and nitrogen) to water bodies from point and diffuse sources.

If proliferation cannot be avoided, it is necessary to invest in corrective measures and remediation of the negative impact of cyanobacteria blooms and their toxic potential (ZHANG et al., 2014). From the point of view of treatment of water supply, the removal of cyanotoxins avoids negative effects on public health due to acute or chronic exposure to them (PANTELÍC et al., 2013). The changes in the water quality due to the cyanobacteria introduce difficulties in its treatment, being the pre-oxidation a possible process for its removal (SILVA et al., 2012). Other alternatives for the removal of cyanotoxins in Water Treatment Stations (ETAs) are described below.

The filtration processes are responsible, among other benefits, for the removal of particles, taste and odour of water, as well as toxins like those produced by cyanobacteria. The performance of rapid filtration facilities is directly related to their physical characteristics, especially the type of water distribution system over the filtering layer and the collection system of the affluent (drains) under the porous bed (SANTOS et al., 2013). In the case of downward filtration. The duration of filtration runs is determined by criteria such as loss of load or occurrence of pollutant overflow. The material that makes up the filter bed, the backwash methods and the variability of the raw affluent water also play a decisive role in the process efficiency. Slow filtration is also an example of a particulate retention system, with substantial removal in the upper portion of the filter medium. Slow filtration is indicated for small communities and springs with relatively low levels of turbidity and total suspended solids in water (FRANCO et al., 2012).

In addition, it is possible to use microfiltration, ultrafiltration, nanofiltration or reverse osmosis (BI et al. 2014). The membranes are effective in the removal of protozoa, bacteria, colloidal matter and water turbidity (GAMAGE \& CHELLAM, 2013). Some of the positive aspects of these technologies are the compact size of the plant, better process control and treated water with a high level of quality (WANG et al., 2013).

The use of activated carbon filters is another option for the efficient removal of several compounds from the water by adsorption phenomena (KEARNS et al., 2014). For advanced treatment of water supply, the use of activated carbon to remove cyanotoxins has been of interest in recent years. The association of the biological activity (biodegradation) to the activated carbon adsorption process has shown to be promising. The use of activated charcoal filters is thus intended to remove pollutants emerging from the water in a final phase of treatment (ERBA et al., 2012).

In activated carbon filtration, some factors must be considered. The molecular weight of the particle, the degree of hydrophobicity of the material to be removed, the charge distribution, the 
contact surface, the porosity of the coal, the $\mathrm{pH}$, the ionic strength and the hardness of the water can influence the performance of the filter in relation to the target pollutant (GILBERT et al., 2013). For selecting what you want to remove, the proper knowledge of the filter medium is essential. Some factors are crucial for the maintenance of these facilities. Backwashes, for example, occur primarily with the use of air and / or water and should be employed when filling the bed to ensure a reduction in the pressure drop acceptable to the operation of the filter.

The existence of biofilms in the activated carbon filters, which represents the incorporation of the biological component into the treatment, can improve its efficiency to produce water for human supply. The interaction of the biofilm with the different processes that occur inside the filter (retention of organic particles, degradation of the solute and predation of other microorganisms) is responsible for the improvement of the quality in the treated water (DERLON et al., 2014).

Minillo et al. (2013) developed a study that evaluated the biodegradation of (D-Leu1) -microcystinLR using microorganisms present in the biofilm of activated carbon filters with biological activity. The authors also carried out the phylogenetic characterization of these microorganisms in the cyanotoxin metabolism process. The results of the research demonstrated that MCs were biodegraded biologically by the action of microorganisms present in the biofilm.

For the evaluation of the quality of water supplied to the population, several variables should be monitored through laboratory protocols. In the case of raw water, when the cyanobacteria density exceeds 20,000 cells.mL-1 in the well, cyanotoxins must be analysed at the point of collection, with weekly frequency. According to Annex VIII of Ordinance 2,914 / 2011 of the Ministry of Health, the maximum permitted value (VMP) in $\mu \mathrm{g} . \mathrm{L}-1$ of microcystins is 1.0. For saxitoxins with the unit in $\mu \mathrm{g}$ equivalent STX.L-1 (saxitoxins.L-1), the VMP is equal to 3.0. Cyanotoxin concentrations should represent the contributions of intracellular fraction and extracellular fraction in the analyzed sample (BRAZIL, 2011). At the exit of the ETA, if cyanotoxins are detected, immediate communication to the haemodialysis clinics and the injectable industries is mandatory. For the control of cyanobacteria, the use of algicides is forbidden.

The main degrading factors of water quality are: mining, construction of dams, plumbing and eutrophication of natural environments that receive evictions resulting from industrial processes and domestic activities. What happens in the surrounding area (land use, whether by residences, agriculture and other types of industries) directly affects water (MACHADO et al., 2015), i.e. interactions of management practices with land uses in the basins Hydrologic processes modulated by the regional climate accelerate the process of eutrophication (COSTA et al., 2014).

These conditions favour the growth of algae due to the higher availability of nutrients and volatile solids in high concentrations that consequently increase the turbidity of suspended organic matter (BRAGA et al., 2015). For example, as the rivers pass through anthropogenic areas, there is an increase 
in the concentrations of soluble P and nitrate, and there is a correlation between the crop and livestock area (CAPOANE et al., 2014).

For the determination of the trophic state of a spring is used the concentration of total phosphorus in a certain area. This is considered as the main element, because the nitrogen can also be assimilated by the atmosphere. For the classification of the trophic states the following terms are used: ultraoligotrophic, oligotrophic, mesotrophic, eutrophic, super trophic and hypereutrophic (BARRETO et al., 2014). When eutrophication occurs, cyanobacteria are one of the most developed organisms.

These organisms are prokaryotes, usually aquatic, that perform photosynthesis with oxygen release, having a wide diversity of forms, due to the morphological, biochemical and physiological adaptations acquired during their long evolutionary process (KURIIAMA et al., 2012). They are also known as blue-green algae. Even though they have characteristics of algae and bacteria, they are classified as bacteria, being free living and solitary organisms and colony formers (CATHERINE et al., 2013).

In the case of macrophyte algae, for example, the community varies among urban reservoirs with different degrees of eutrophication. Some algae occur in specific areas and others are present in environments with different characteristics (SILVA et al., 2014).

To prevent the proliferation of these species, it is necessary to interrupt the release of organic material rich in $\mathrm{N}$ and $\mathrm{P}$, either from point sources or diffuse sources, considering that the episodes of toxic algal blooms occur in rivers, lakes and coastal areas (RIVETTI., et al). When the biological, physical and chemical treatment of wastewater is made, the possibility of cyanobacteria blooms greatly reduces, and the discharge of sewage increases the risk of the presence of cyanotoxins in waters that can be used in abstraction for human consumption (BARRINGTON et al., 2013). Compounds that confer flavour and smell to water are also released into the water by cyanobacteria (MEREL et al., 2013).

The presence of toxin-producing cyanobacteria in water for human consumption or recreational purposes has long been neglected or even treated at the local level. Cyanotoxins are metabolites of derivatives of different cyanobacteria cells with high chemical diversity, and these toxins are considered a health risk due to their high-water solubility, toxicity and chemical stability (PELAEZ et al., 2013).

Bioaccumulation of these toxins may also pose risks to wildlife and domestic wildlife (PINHO et al., 2015). In a study conducted with the objective of evaluating the disinfection of shrimp contaminated with microcystin LR, the bioaccumulation was verified in the animals under study, where biochemical disturbances were observed (GALANTI et al., 2013). 
In addition to the cylinderspermopsin and the anatoxin-a, the main types of cyanotoxins include microcystins and saxitoxins (HO et al., 2012). Microcystins are present in the cells of cyanobacteria and their concentration may be greater in the senescence of the organism.

In both freshwater and saltwater microcystins can be found (RASTOG et al., 2013). These are the most studied cyanobacteria toxins, since they are widely distributed in the world (BITTENCOURTOLIVEIRA et al., 2014). In Brazil, the maximum allowable amount of microcystin in the water used in the human supply is $1.0 \mu \mathrm{g} / \mathrm{L}$. For saxitoxins the maximum allowed value is equal to $\mu \mathrm{g}$ STX / L equivalent (BRAZIL, 2011).

In relation to saxitoxins, some countries that had the detection of saxitoxins in freshwater are Australia and the United States, where the LD50 value of the most toxic variant was $10 \mu \mathrm{g} / \mathrm{kg}$ after the injection. Cyanotoxins are potent inhibitors of serine / threonine phosphatases (MEREL et al., 2013).

Coagulation systems - flocculation, sedimentation, filtration by sand filters, the use of filter membranes, activated charcoal, ultraviolet radiation, ozonisation and chlorination are important systems that help to remove cyanotoxins (MEREL et al., 2013). In the treatment of water, there are still no single techniques capable of removing all the cyanotoxin-generating cells at once and these microsolutes dissolved in water (ROMERO et al., 2014).

For the control of cyanobacteria that cause eutrophication the application of chemicals is an inexpensive method. Its effects, however fast and effective, present high toxicity to non-target species, as well as persistence in the environment (JANCULA et al., 2014). The use of algicides leads to the release of intracellular toxins and inhibits the degrading activity of microorganisms (FAN et al., 2014).

Another way to destroy the amino acids from cyanobacteria is through ultraviolet (UV) radiation, where direct photolysis of microcystins and free radicals occurs. Some studies have already been carried out in detail with the purpose of providing modeling subsidies and also applications of oxidative processes in the microcystins variants (HE et al., 2015).

By using the biodegradation of hepatotoxin (D-Leu1)-microcystin-LR by bacteria present in biological filters of coal can verify the biodegradation of microcystins via the action of the microorganisms present in the biofilm of organic carbon filters (CAB). One of the ways to detect these microorganisms is through the resonance in which it uses fluorescence to detect the presence of cyanotoxins in water (WU et al., 2015).

The potential for metabolism of cyanotoxins by microbial components present in biofilters was verified, where a natural degradation of hepatotoxin occurred, which although reduced in relation to the treatments containing biofilm microorganisms in CAB filters, should be considered in the final removal balance. It was observed the microtactic effect of microcystins by the microorganisms 
maintained under the presence of hepatotoxin occurring bacterial dominance in the cultivated isolates of CAB filters, being represented by four genera and two families of bacteria (MINILLO et al., 2013).

Water treatment plants (ETAs) that use full cycle treatment (using coagulation, flocculation, decantation and filtration processes and operations for water clarification, followed by disinfection, fluorination and final stabilization) are efficient in the removal of cyanotoxins. These are present in 63.3\% of Brazilian municipalities (BARTIKI \& JULIO, 2015).

In a study carried out in 2010, where the objective was to reveal the dynamics between the biodegradability of microcystin-LR and the potential intervening factors in this process, biofilms were examined through biological treatments, with biofilms being evaluated throughout the year 2010 (L, et al., 2005). In the present study, the biodegradability of microcystin-LR was correlated with factors such as water temperature and the concentration of cyanotoxins and chlorophyll a (LI et al., 2015).

In the use of ultraviolet radiation in a photocatalytic process on aeruginous cells, the removal of microcystins-LR was evaluated using well water with cyanobacteria. The photocatalytic process was successful in the removal of intra- and extracellular cyanotoxins, and in water with high cyanobacterial cell density, a prefiltration can be included, where it was reduced to cell lysis. Another option is the use of photocatalytic oxidation (PINHO et al., 2015).

The variation of the growth rate, the generation of reactive oxygen promoter species and the responses of several antioxidants in $\mathrm{M}$. aeruginosa after exposure to amoxicillin, as well as the biodegradation of amoxicillin by M. aeruginosa, were investigated, with the biodegradation of Some components were directly related to $\mathrm{N}$ levels (LIU et al., 2015).

Oxidative processes are also ways of removing emerging pollutants, including cyanotoxins. In a study carried out where the oxidation of permanganate was used, the efficacy of the system was proven, proving to be efficient to catalyse the oxidation of organic groups rich in permanganate electrons (PELAEZ et al., 2013).

Sedimentation, coagulation / flocculation, aims to remove algae in larger dimensions, and physical disturbances may increase cell lysis. In ozonating and ultraviolet disinfection it is possible to treat the cell surface where the toxicity is high. Activated carbon is technology that has $99 \%$ efficiency. Chlorination and use of permanganate are efficient in the removal of soluble microcysts. Nanofiltration and ultrafiltration technologies use pressure that causes the water to be oriented to small pores with the focus of removing pathogens and contaminants that are not usually removed in the filtration of coarse solids (ROEGNER et al., 2014).

According to Vlad et al (2014, p. 603) for the extracellular removal and degradation of cyanotoxins, the following treatments can be used: oxidation, chlorine use, chloramines and chlorine dioxide, ozone, advanced oxidative processes), Permanganate, membrane filtration, UV radiation, adsorption, granular activated carbon, activated carbon powder, biofiltration and slow filtration. 
The biodegradation of cyanotoxins is still somewhat difficult to apply in countries with a tropical climate due to the hot climate (VLAD et al., 2014). In a three-year study, the efficiency of the use of a composite for the removal of cyanotoxins from water was analyzed, being this effective in the removal of dissolved microcystin (KIM et al., 2012).

The antialgae extracted from plants and microorganisms and the use of inhibitors, are alternatives in the biological control of cyanotoxin expansion in a natural environment (SHAO et al., 2013). Secondary metabolites generated by cyanobacteria (geosynes and also 2-ethylenebisoborneol - MIB) cause problems related to taste and also odor, causing harm to human health (HO et al., 2012).

Denitrification is indicated as one of the biological processes used for centuries in the treatment of water for human consumption. One of the advantages of this technology is the need for the addition of chemicals, being these potential producers of by-products harmful to human health (HO et al., 2012).

Methylobacillus sp, Lactobacillus rhamnosus strains GG and LC-705, Bifidobacterium longum 46, Bifidobacterium lactis strains 420 and Bb12, can remove several types of microcystins, although almost all studies on the genotypic degradation of microcystin have focused on Sphingomonadaceae. With the use of the enzyme phosphatase was observed the non-formation of by-products of the reaction (HO et al., 2012).

In the removal of saxitoxins something pointed was the use of anthracite, being this evident if compared with filters where only the presence of sand existed. In the case of anatoxin-a, activated carbon filters are still the best solution for the removal in water treatment processes for human supply (HO et al., 2012).

In the removal of microcystins of the LR type by means of microorganisms removed from nature, environmental factors such as temperature and $\mathrm{pH}$ of the water in the degradation of these compounds were evaluated, where the changes in the structure of the bacterial community under different cultural conditions through the process of an anoxic biodegradation was identified in microorganisms responsible for biodegradation of metabolites (MA et al., 2014).

Factors such as the characterization of biofilm potential in the degradation of microcystins during the winter, besides the identification of the effect of phosphate, glucose, nitrate and glucose, the kinetic relationships between microorganisms and the effects of nutrients on the population of the biofilm were evaluated and presented results related to the deceleration of phosphate, glucose and nitrate + glucose combination biodegradation. The microcystin-producing microcystin population can be affected with the presence of nutrients in the water (LI et al., 2012).

The degradation potential of some bacteria found in natural water sediments in six-day trials was 13 to $15 \%$ for the microcystin used in the study. In this study, the removal rates were 44 and $31 \%$, with the researchers suggesting that the increased adaptability of the bacteria obtained through 
concentrated natural media was responsible for the reinforced biodegradation, which continued under simulated water conditions Natural (LI \& PAN, 2014).

In the biological removal of cyanotoxins promoted by specific strains, some factors related to removal efficiency are: temperature, $\mathrm{pH}$, viability and bacterial cell density.

\section{Conclusions}

Brazilian law and standards about water quality is one of the best in the world. Even though we need to invest more in waste water treatment in the country, for example, we have a nice system of water treatment, but new technologies are necessary to be adopted. Powdered carbon activated is one nice technology, and not expensive comparing with ones presented in this work.

\section{References}

AL-SAMMAK, M. A; HOAGLAND, K. D; CASSADA, D; SNOW, D. D. Co-occurrence of the Cyanotoxins BMAA, DABA and Anatoxin-a in Nebraska Reservoirs, Fish, and Aquatic Plants. Toxins, Switzerland, v. 6, p. 488-508, Jan. 2014.

ANDRADE, R. R \& GIROLDO, D. Limnological characterisation and phytoplankton seasonal variation in a subtropical shallow lake (Guaiba Lake, Brazil): a long-term study. Acta Limnologica Brasiliensia, Rio Claro, v. 26, n. 4, p. 442-456, Oct./Dec. 2014.

AWWA - American Water Works Association. Water quality and treatment: a handbook on drinking water. In: Edzwald, J.K. (editor). Colorado: McGraw-Hill, 2010. 1.696p.

AWWA \& ASCE - American Water Works Association \& American Society of Civil Engineers. Water treatment plants design. Estados Unidos: AWWA/ASCE, 2005.

BARRETO, L. V; FRAGA, M. C; BARROS, F. M; ROCHA, F. A; AMORIM, J. S; CARVALHO, S. R; BONOMO, P; SILVA, D. P. Relation between flow and water quality in a river section. Revista Ambiente \& Água, Taubaté, v. 19, n. 1, p. 118-129, Jan./Mar. 2014.

BARRINGTON, D. J.; GHADOUANI, A.; IVEY, G. N. Cyanobacterial and microcystins dynamics following the application of hydrogen peroxide to waste stabilisation ponds. Hydrology And Earth System Sciences, v. 15, p. 2097-2105, May. 2013.

BARTIKO, D \& JULIO, D. M. Construction and use of coagulation diagrams as a tool for continuous monitoring of flocculation in water supply. Revista Ambiente \& Água, Taubaté, v. 10, n. 1, p. 71-81, Jan./Mar. 2015 Epub Mar-2015.

BERTOSSI, A. P. A; CECÍLIO, R. A; NEVES, M. A; GARCIA, G. O. Water quality in watersheds with different soil cover in southern Espírito Santo. Revista Árvore, Viçosa, v. 37, n. 1, p. 107-117, Jan./Feb. 2013.

BI, F; ZHAO, H; ZHANG, L; YE, Q; CHEN, H; GAO, C. Discussion on calculation of maximum water recovery in nanofiltration system. Discussion on calculation of maximum water recovery in nanofiltration system. Desalination, USA, v. 332, p.142-146, Jan. 2014.

BITTENCOURT-OLIVEIRA, M. C.; HEREMAN, T. C.; ARAÚJO, M. K. C.; MACEDO-SILVA, I.; DIAS, C. T.; SASAKI, F. F. C.; MOURA, A. N. Phytotoxicity associated to microcystins: a review. Brazilian Journal of Biology, São Carlos-SP, v. 74, n. 4, p. 753-760, Nov. 2014 Epub Nov-2014. 
BOUTILIER, M. S. H; LEE, J; CHAMBERS, V; VENKATESH, V; KARNIK, R. Water Filtration Using Plant Xylem. Plos One, USA, v. 9, Issue 2, p. 1-8, Feb. 2014.

BRAGA, G. G.; BECKER, V.; OLIVEIRA, J. N. P.; MENDONÇA JUNIOR, J. R.; BEZERRA, A. F. M.; TORRES, L. M.; GLAVÃO, A. M. F.; MATTOS, A. Influence of extended drought on water quality in tropical reservoirs in a semiarid region. Acta Limnologia Brasiliensia, Rio Claro, v. 27, n. 1, p. 1523, Jan./Mar. 2015.

BRASIL. Ordinance no 2.914, 12th December, 2011. Provides on the procedures of control and monitoring of the quality of water for human consumption and its standard of potability. Disponível em: <http://bvsms.saude.gov.br/bvs/saudelegis/gm/2011/prt2914_12_12_2011.html>. Access: January, 2017.

Ministry of Health. Health Surveillance Secretariat. Department of Environmental Health Surveillance and Worker's Health. Cyanobacteria / cyanotoxins: collection, preservation and analysis procedures. Ministry of Health, Secretariat of Health Surveillance, Department of Surveillance in Environmental Health and Worker's Health. - Brasília: Ministry of Health, 2015. 106 p.: il.

BRIDGEMAN, J; GULLIVER, P; ROE, J; BAKER, A. Carbon isotopic characterisation of dissolved organic matter during water treatment. Water Research, USA, v. 48, p. 119-125, Jan. 2014.

CAPOANE, V.; TIECHER, T.; SCHAEFER, G. L.; CIOTTI, L. H.; SANTOS, D. R. Transfer of nitrogen and phosphorus to surface waters in a watershed with agriculture and intensive livestock production in southern Brazil. Ciência Rural, Santa Maria, v. 45, n. 4, p. 647-650, abr. 2015 Epub 11Nov-2014.

CATHERINE, Q.; SUSANNA, W.; ISIDORA, E-S.; MARK, H.; AURÉLIE, V.; JEAN-FRANÇOIS, H. A review of current knowledge on toxic benthic freshwater cyanobacteria e Ecology, toxin production and risk management. Water Research, USA, v. 47, p. 5464-5479, 2013.

COSTA, S. M.; APPEL, E.; MACEDO, C. F.; HUSZAR, V. L. M. Low water quality in tropical fishponds in southeastern Brazil. Anais da Academia Brasileira de Ciências, Rio de Janeiro, v. 86, n. 3, p. 1181-1195, set. 2014.

DERLON, N; MIMOSO, J; KLEIN, T; KOETZSCH, S; MORGENROTH, E. Presence of biofilms on ultrafiltration membrane surfaces increases the quality of permeate produced during ultra-low pressure gravity-driven membrane filtration. Water Research, USA, v. 60, p. 164-173, Sept. 2014.

DONG, L; LIU, W; JIANG, R; WANG, Z. Physicochemical and porosity characteristics of thermally regenerated activated carbon polluted with biological activated carbon process. Bioresource Technology, USA, v. 171, p. 260-264, Nov. 2014.

ERBA, C. M; TANGERION, E. P; CARVALHO, S. L; ISIQUE, W. D. Removal of diclofenac, ibuprofen, naproxen and paracetamol in a biological filter followed by a biologically activated granular carbon filter. Engenharia Sanitária e Ambiental, Rio de Janeiro, v. 17, n. 2, p. 137-142, Apr./Jun. 2012.

FAN, J.; HOBSON, P.; HO, L.; DALY, R.; BROOKES, J. The effects of various control and water treatment processes on themembrane integrity and toxin fate of cyanobacteria. Journal of Hazardous Materials-Elsevier, USA, v. 264, p. 313-322, Jan. 2014.

FRANCO, M; SILVA, G. K; PATERNIANI, J. E. S. Water treatment by multistage filtration system with natural coagulant from Moringa oleifera seeds. Engenharia Agrícola, Jaboticabal, v. 32, n. 5, p. 989-997, Sept./Oct. 2012.

GALANTI, L. N.; AMÉ, M. V.; WUNDERLIN, D. A. Accumulation and detoxification dynamic of cyanotoxins in the freshwater shrimp Palaemonetes argentines. Harmful Algae-Elsevier, USA, v. 27, p. 88-97, Jul. 2013. 
GAMAGE, N. P \& CHELLAM, S. Mechanisms of Physically Irreversible Fouling during Surface Water Microfiltration and Mitigation by Aluminum Electroflotation Pretreatment. Environmental Science and Technology, USA, v. 48, p. 1148-1157, Dec. 2013.

GILBERT, O; LEFÈVRE, B; FERNÁNDEZ, M; BERNAT, X; PARAIRA, M; PONS, M. Fractionation and removal of dissolved organic carbon in a full-scale granular activated carbon filter used for drinking water production. Water Research, USA, v. 47, Issue 8, p. 2821-2829, May. 2013.

HE, X.; CRUZ, A. A. L.; HISKIA, A.; KALOUDIS, T.; O'SHEA, K.; DIONYSIOU, D. D. Destruction of microcystins (cyanotoxins) by UV-254 nm-based direct photolysis and advanced oxidation processes (AOPs): Influence of variable amino acids on the degradation kinetics and reaction mechanisms. Water Research, USA, v. 74, p. 227-238, May. 2015.

HO, L.; SAWADE, E.; NEWCOMBE, G. Biological treatment options for cyanobacteria metabolite removal - A review. Water Research, USA, v. 46, p. Issue. 5, p. 1536-1548, Ap. 2012.

JANCULA, D.; MIKULA, P.; MARSALEK, B.; RUDOLF, P.; POCHYLÝ, F. Selective method for cyanobacterial bloom removal: hydraulic jet cavitation experience. Aquaculture International, USA, v. 22, Issue. 2, p. 509-521, Ap. 2014.

JARDIM, F. A; VON SPERLING, E; JARDIM, B. F. M; ALMEIDA, K. C. B. Determinants of cyanobacterial blooms in the water of the Doce River, Minas Gerais, Brazil. Engenharia Sanitária e Ambiental, Rio de Janeiro, v. 19, n. 3, p. 207-218, Jul./Sept. 2014.

JING, G; WANG, L; YU, H; AMER, W. A; ZHANG, L. Recent progress on study of hybrid hydrogels for water treatment. Colloids and Surfaces A: Physicochemical and Engineering Aspects, USA, v. 416, p. 86-94, Jan. 2013.

KAUFMAN, Y; GRINBERG, S; LINDER, C; HELDMAN, E; GILRON, J; SHEN, Y-X; KUMAR, M; LAMMERTINK, R. G. H; FREGER, V. Towards supported bolaamphiphile membranes for water filtration: Roles of lipid and substrate. Journal of Membrane Science, USA, v. 457, p. 50-61, May. 2014.

KEARNS, J. P; WELLBORN, L. S; SUMMERS, R. S; KNAPPE, D. R. U. 2,4-D adsorption to biochars: Effect of preparation conditions on equilibrium adsorption capacity and comparison with commercial activated carbon literature data. Water Research, USA, v. 62, p. 20-28, Oct. 2014.

KIM, B-H.; LEE, J-H.; HWANG, S-J. Removal of Cyanobacteria and Microcystin by Natural PlantMineral Combinations in Eutrophic Waters. Bulletin of Environmental Contamination and Toxicology, USA, v. 90, p. 216-221, Feb. 2013.

KURIAMA, F.; KURODA, E. K.; GUERGOLETTO, K. B.; GARCIA, S.; NOBREGA, G. M. A.; TSUJI, K.; HARADA, K-I.; HIROOKA, E. Y. Potential of biodegradation of microcystins by microorganisms. Engenharia Sanitária e Ambiental, Rio de Janeiro, v. 17, n. 2, p. 181-186, Ap./Jun. 2012.

LI, J.; SHIMIZU, K.; AKASAKO, H.; LU, Z.; AKIYAMA, S.; GOTO, M.; UTSUMI, M.; SUGIURA, N. Assessment of the factors contributing to the variations in microcystins biodegradability of the biofilms on a practical biological treatment facility. Bioresource Technology, USA, v. 175, p. 463472, Jan. 2014.

LI, H \& PAN, G. Enhanced and continued degradation of microcystins using microorganisms obtained through natural media. Journal of Microbiological Methods, v. 96, p. 73-80, Jan. 2014.

.; MASEDA, H.; LU, Z.; UTSUMI, M.; ZHANG, Z.; SUGIURA, N. Investigations into the biodegradation of microcystin-LR mediated by the biofilm in wintertime from a biological treatment facility in a drinking-water treatment plant. Bioresource Technology, v. 106, p. 27-35, 2012. 
LIU, Y.; WANG, F.; CHEN, X.; ZHANG, J.; GAO, B. Cellular responses and biodegradation of amoxicillin in Microcystis aeruginosa at different nitrogen levels. Ecotoxicology and Environmental Safety, USA, v. 111, p. 138-145, Jan. 2015.

LOPES, F. B; ANDRADE, E. M; MEIRELES, A. C. M; BECKER, H; BATISTA, A. A. Assessment of the water quality in a large reservoir in semiarid region of Brazil. Revista Brasileira de Engenharia Agrícola e Ambiental, Campina Grande, v. 18, n. 4, p. 437-445, Ap. 2014.

MA, G.; PEI, H.; HU, W.; XU, X.; MA, C.; LI, X. The removal of cyanobacteria and their metabolites through anoxic biodegradation in drinking water sludge. Bioresource Technology, USA, v. 165, p. 191-198, Aug. 2014.

MACHADO, N. G.; NASSARDEN, D. C. S.; SANTOS, F.; BOAVENTURA, I. C. G.; PERRIER, G.; SOUZA, F. S. C.; MARTINS, E. L.; BIUDES, M. S. Chironomus larvae (Chironomidae: Diptera) as water quality indicators along an environmental gradient in a neotropical urban stream. Revista Ambiente \& Água, v. 10, n. 2, p. 298-309, abr.jun. 2015 Epub Abr-2015.

MEREL, S.; WALKER, D.; CHICANA, R.; SNYDER, S.; BAURÈS, E.; THOMAS, O. State of knowledge and concerns on cyanobacterial blooms and cyanotoxins. Environment International, v. 59, p. 303327, Sept. 2013.

MINILLO, A.; FREITAS, S. C.; ISIQUE, W. D.; PRADO, H. F. A.; DIMITROV, M. R.; PAIXÃO, D. A. A.; LEMOS, E. G. M.; TANGERIONO, E. P. Biodegradação da hepatotoxina (D-Leu1)-microcistina-LR por bactérias presentes em filtros biológicos de carvão. Engenharia Sanitária e Ambiental, Rio de Janeiro, v. 18, n. 3, p. 205-214, July/Sept. 2013.

NAM, S-W; CHOI, D-J; KIM, S-K; HER, N; ZOH, K-D. Adsorption characteristics of selected hydrophilic and hydrophobicmicropollutants in water using activated carbon. Journal of Hazardous Materials, USA, v. 270, p. 144-152, Ap. 2014.

OGASHAWARA, I; ZAVATTINI, J. A; TUNDISIC, J.G. The climatic rhythm and blooms of cyanobacteria in a tropical reservoir in São Paulo, Brazil. Brazilian Journal of Biology, São Carlos, v. 74, n. 1, p. 72-78, Feb. 2014.

PANTELÍC, D.; SVIRCEV, Z.; SIMEUNOVIC, J.; VIDOVIC, V.; TRAJKOVIC, I. Cyanotoxins: Characteristics, production and degradation routes in drinking water treatment with reference to the situation in Serbia. Chemosphere, USA, v. 91, p. 421-441, 2013.

PELAEZ, M.; BARUWATI, B.; VARMA, R. S.; LUQUE, R.; DIONYSIOU, D. D. Microcystin-LR removal from aqueous solutions using a magnetically separable $\mathrm{N}$-doped $\mathrm{TiO} 2$ nanocomposite under visible light irradiation. Chemical Communications, UK, v.49, p.10118-10120, 2013.

PINHO, L. X.; AZEVEDO, J.; BRITO, A.; SANTOS, A.; TAMAGNINI, P.; VILAR, V. J. P.; VASCONCELOS, V. M.; BOAVENTURA, R. A. R. Effect of TiO2 photocatalysis on the destruction of Microcystis aeruginosa cells and degradation of cyanotoxins microcystin-LR and cylindrospermopsin. Chemical Engineering Journal - Elsevier, USA, v. 268, p. 144-152, May. 2015.

RASTOG, R. P.; SINHA, R. P.; INCHAROENSAKDI, A. The cyanotoxin-microcystins: current overview. Reviews in Environmental Science and Bio/Technology, USA, v. 13, Issue. 2, p. 215-249, Feb. 2014.

RESTANI, G. C \& FONSECA, A. L. Effects of Cylindrospermopsis raciborskii strains (Woloszynska, 1912) Senayya \& Subba Raju on the mobility of Daphnia laevis (Cladocera, Daphniidae). Brazilian Journal of Biology, São Carlos, v. 74, n. 1, p. 23-31, Feb. 2014.

RIVETTI, C.; GÓMEZ-CANELA, C.; LACORTE, S.; BARATA, S. Liquid chromatography coupled with tandem mass spectrometry to characterise trace levels of cyanobacteria and dinoflagellate toxins in suspended solids and sediments. Analytical and Bioanalytical Chemistry, USA, v. 407, Issue 5, p. 1451-1462, Feb. 2015. 
ROEGNER, A. F.; BRENA, B.; GONZÁLEZ-SAPIENZA, G.; PUCHNER, B. Microcystins in potable surface waters: toxic effects and removal strategies. Journal of Applied Toxicology, v. 34, p. 441457, May. 2014.

ROMERO, L. G.; MONDARDO, R. I.; GRISCHEK, T. Removal of cyanobacteria and cyanotoxins during lake bank filtration at Lagoa do Peri, Brazil. Clean Technologies And Environmental Policy, USA, v. 16, p. 1133-1143, Feb. 2014.

SANTOS, M. B; MESQUITA, M; TESTEZLAF, R. Application of wind tunnel in the evaluation of flow lines generated by crepins of sand filters. Engenharia Agrícola, Jaboticabal, v. 33, n. 3, p. 548-559, May/Jun. 2013.

SHAO, J.; LI, R.; LEPO, J. E.; GU, J-D. Potential for control of harmful cyanobacterial blooms using biologically derived substances: Problems and prospects. Journal of Environmental Management, v. 125, p. 149-155, Aug. 2013.

SILVA, S. C. A.; SERVI, A. C.; BONA, C.; PADIAL, A. A. Aquatic macrophyte community varies in urban reservoirs with different degrees of eutrophication. Acta Limnologica Brasiliensia, Rio Claro, v. 26, n. 2, p. 129-142, Ap./Jun. 2014.

SILVA, G. G; NAVAL, L. P; DI BERNARDO, L; DANTAS, A. D. B. Treatment of reservoir water by double filtration, oxidation and adsorption on granular activated carbon. Engenharia Sanitária e Ambiental, Rio de Janeiro, v. 17, n. 1, p. 71-80, Jan./Mar. 2012.

SORLINI, S; GIALDINI, F; COLLIVIGNARELLI, C. Removal of cyanobacterial cells and MicrocystinLR from drinking water using a hollow fiber microfiltration pilot plant. Desalination, USA, v. 309, p. 106-112, Jan. 2013.

TIAN, J; LU, J; ZHANG, Y; LI, J-C; SUN, L-C; HU, Z-L. Microbial Community Structures and Dynamics in the O3/BAC Drinking Water Treatment Process. International Journal of Environmental Research and Public Health, USA, v. 11, p. 6281-6290, Jun. 2014.

VLAD, S.; ANDERSON, W. B.; PELDSZUS, S.; HUCK, P. M. Removal of the cyanotoxin anatoxin-a by drinking water treatment processes: a review. Journal of Water and Health, v. 12, p. 601-617, Dec. 2014.

WANG, S; LIU, C; LI, Q. Impact of polymer flocculants on coagulation microfiltration of surface water. Water Research, USA, v. 47, Issue. 13, p. 4538-4546, Sep. 2013.

WU, S.; DUAN, N.; ZHANG, H.; WANG, Z. Simultaneous detection of microcysin-LR and okadaic acid using a dual fluorescence resonance energy transfer aptasensor. Analytical and Bioanalytical Chemistry, USA, v. 407, Issue 5, p. 1303-1312, Feb. 2015.

ZHANG, H; YANG, L; YU, Z; HUANG, Q. Inactivation of Microcystis aeruginosa by DC glow discharge plasma: Impacts on cell integrity, pigment contents and microcystins Degradation. Journal of Hazardous Materials, USA, v. 268, p. 33-42, Mar. 2014. 